金属および合金の高温変形挙動

\title{
5. 熱間圧延における板クラウンおよび板形状の造形性*
}

\author{
中島 浩 衛** 菊 間 敏 夫*** 松 本 紘 美****
}

\section{1 緒言}

近年, 自動車, 家庭用電気機器, 容器, 建材など薄 鋼板を使用する諸産業の急速な発展拉よび需要増大は， 鋼板およびストリップ製造技術を著しく進歩させてき た.このような情勢のもとで製品品質に対する需要家 の要求は一段と厳しいものとなり, 材質特性は勿論, 板厚, 形状, クラウン等の寸法精度の高精度化が強く 要望されるようになった。

板形状に関しては通常の 4 段圧延機においてワーク ロールベンディング装置によってかなり広範な圧延条 件に対して形状制御が可能である. 一方板クラウンに 関しては通常の 4 段圧延機では効果的な制御手段がな かったためにクラウン, プロフィル制御法の顕著な進 歩が得られなかったのが現状である.

ホットストリップを例にとると，鋼種によって所望 の板クラウンが異り, 冷延材の場合は冷間圧延性の面 から適度な大ささのクラウン值を必要とするが, 熱延 板として使用する場合はデッドフラット(クラウン0) が要求される. しかもこの板クラウンはロール組替直 後から次の組替までのロール熱膨張扣よび摩耗による ロールプロフィールの時系列的変化に対しても常に一 定值を確保することが必要とされるため, クラウン制 御法の重要性がある.

ホットストリップのクラウン制御法として従来より 操業技術面から圧延鋼種に合ったロールカーブ調整, 仕上げ圧延負荷配分調整, 仕上トータルフォース制御 などの努力がはらわれてきた。

一方設備面では 4 段圧延機でのワークロールベンダ 一が主体であったが，その制御機能が不充分なために， さらにワークロールベンド力を強化した方法としてダ ブルチョックベンダー (DCB) の提案が行われている. さらには異径ロール駆動に代表される上下ロールの異 速圧延による荷重減少効果の利用などもある。また口 ール変形をより容易に行らことによって板形状, 板ク

\footnotetext{
* 原稿受理 昭和56年 2 月 19 日

** 正会員 新日本製鉄(株)生産技術研究所

北九州市八幡東区枝光

*** 新日本製鉄(株)八幡製鉄所 北九州市八幡東区枝光

**** 新日本製鉄(株)生産技術研究所 北九州市八幡東区枝光
}

ラウン制御機能を拡大した $6 \mathrm{Hi}$ 中間ロールシフトミ ルが開発された。

本報告はホットストリップミルに拈ける板クラウン 制御法を中心に板形状と関連させながら最近の新しい 技術動向について述べる.

\section{2 圧延における板形状, クラウンの圧延理論}

\section{$2 \cdot 1$ 板クラウン変化と板形状の関係}

図 1 に示すように上下の 2 本ロール間で生ずる断面 形状，すなわちクラウンは，ロールの弾性たわみ拉よ びロール扁平变形に基づいて材料横断面プロフィール が変化することによって，板クラウン抒よび板平面形 状が中伸び，端伸び，あるいはこれらの組合せ形状不 良,ささらに目的とするフラットな形状などが得られ る.

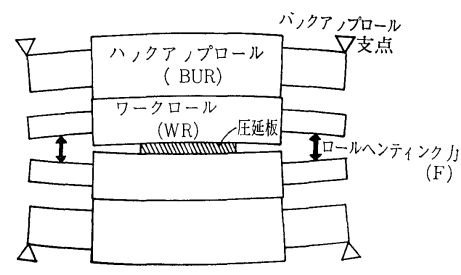

図14 Hi ミルのロール変形と圧延材の断面変形

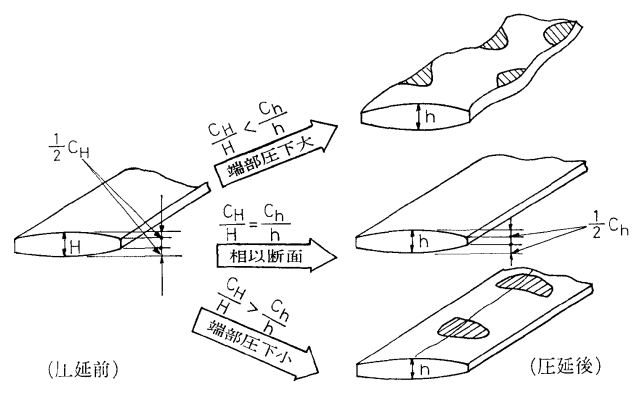

図 2 板クラウン変化と形状の関係

板クラウンは図 2 に示すように $C_{h}=h_{c}-h_{20}$ で表さ れ, 板幅中心の板厚 $h_{c}$ 之板端部 $20 \mathrm{~mm}$ 点の板厚 $h_{20}$ との差で定義する. 圧延前の板クラウン $C_{H}$ が压延後 の板クラウン $C_{h}$ となるとき，圧延前の板クラウン比 率 $C_{H} / H$ と圧延後の板クラウン比率 $C_{h} / h$ の大小関 
係によって，すなわち断面内の幅方向位置によるクラ ウン比率の不一致によって形状が支配される。すお ち $C_{H} / H=C_{h} / h$ のとさフラットな形状であり, $C_{H} /$ $H>C_{h} / h$ のとき中伸び, $C_{H} / H<C_{h} / h$ のとき端伸び となる．したがって一般に形状は板クラウン変化によ る場所による延伸差 $\Delta \varepsilon_{h}$ ((1)式) によって表される.

クラウン変化に基づく延伸差

$$
\Delta \varepsilon_{h}=\frac{C_{h} / h-C_{H} / H}{1-C_{H} / H}
$$

\section{$2 \cdot 2$ 形状，クラウンの圧延理論}

$2 \cdot 2 \cdot 1$ ロールの変形式 6 段圧延機を含めて一 般に多段圧延機のロール変形を簡明なロジックで解析 できることが必要であり, 等価 $2 \mathrm{Hi}$ ミルの概念を導 入して, 積分方程式をマトリックス表示して数值計算 を行うといら方法について述べる.

まず図 3 に示すような両端を支持した円柱はり（バ ックアップロール (BUR) がこれに相当する) に, $p_{0}(x)$ といら分布線荷重が加わったときの軸心の変形 は材料力学より次式で与えられる.

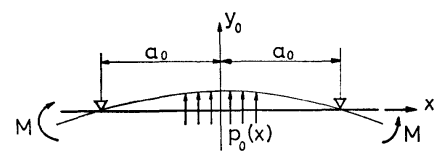

図 3 円柱はりの変形

$$
y_{0}(x)=\int_{-l}^{l} K_{0}(x, \xi) p_{0}(\xi) d \xi+\frac{M}{2 \cdot \frac{\pi}{4} E R^{4}}\left(x^{2}-a_{0}^{2}\right)
$$

（ $l$ ：ロールバレル中央部を原点にとり，荷 重がかかっている範囲)

ただし，

$$
\begin{aligned}
K_{0}(x, \xi)= & \frac{1}{6 a_{0}}\left(a_{0}-\xi\right)\left(a_{0}+x\right) \\
& \times\left(\frac{a_{0}{ }^{2}-\frac{1}{2}\left(\xi^{2}+x^{2}\right)+a_{0}(\xi-x)}{\frac{\pi}{4} E R^{4}}\right. \\
& \left.+\frac{3}{\frac{3}{4} \pi G R^{2}}\right)
\end{aligned}
$$

ここで, $E, G$ : ロールの縦剛性係数おうよび横剛 性係数

$$
R: \text { ロール半径 }
$$

$M:$ 支持点に打けるモーメント

つぎに, 図 4 に示すように, 上方にいくつかのロー ル系によって支持されているロール（図 4 ではワーク ロール）の変形も(2)式と同様に(4)式のように表すこと を考光る。

$$
y(x)=\int_{-l}^{l} K(x, \xi) p(\xi) d \xi+f(x)
$$

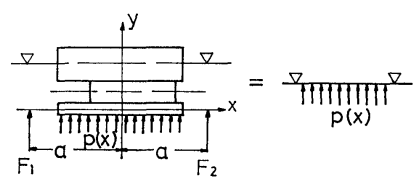

図 4 等価 $2 \mathrm{Hi}$ ミル

この式は積分核 $K(x, \xi)$ や一定関数 $f(x)$ は BUR の それとは異るが形式的には同じ形で表されており，こ の意味で(4)式で変形を表したとき，これを等価 $2 \mathrm{Hi}$ ミルの変形と呼ぶ.

このよらにして図 4 に示すロール系の等価 $2 \mathrm{Hi}$ ミ ルが得られるから, 初めに BUR のみの系から出発し, 順次ロールの数を増していくことによって，一般に多 段圧延機の等価 $2 \mathrm{Hi}$ ミル，すなわち(4)式に和ける関 数 $K, f$ が求められる.

こうして, 直接圧延材と接するワークロールの軸心 の変形が(4)式で与えられ，これにワークロールと板と の間の扁平変形を加えて，圧延中のワークロール表面 の形が(5)式で与えられる.

$$
y_{s}(x)=\int_{-l}^{l} K_{s}(x, \xi) p(\xi) d \xi+f(x)
$$

出口板厚分布は上・下ロールが点対称の関係にあるこ とから，

$$
\begin{aligned}
& \frac{1}{2} h(x)+\text { const } \\
& \quad=\frac{1}{2}\left\{y_{s}(x)+y_{s}(-x)\right\} \\
& \quad=\int_{-l}^{l} \bar{K}(x, \xi) p(\xi) d \xi+\bar{f}(x)
\end{aligned}
$$

が成立する.

$2 \cdot 2 \cdot 2$ 板クラウンを求める方程式系 板クラウ ソ拉よび伸び分布を計算するための方程式を列挙する と以下のよらになる。

ロール変形式は(6)式より,

$$
\frac{1}{2} h(x)=\int_{-l}^{l} \bar{K}(x, \xi) p(\xi) d \xi+\bar{f}(x)+C
$$

ここで，CはBUR の支持点位置に関する未知定数 であり， $\bar{K}, \bar{f}$ は2・2・1 節で述べたように既知関数 であり，pは方程式を解いて求めるべき未知の荷重分 布である。

出側張力分布（未知） $\sigma(x)$ に関するつりあい条件 は(8)式で，

$$
\int \sigma(\xi) h(\xi) d \xi=T \text { (出側全張力) }
$$

なた, 出側張力分布と出側板厚分布との関係は(9)式で 表される。

$$
h(x)=h_{0}(x)\left\{1+\frac{\sigma(x)}{E_{p}(x)}-w(x)\right\}
$$

ここで， $h_{0}(x)$ は基準板厚分布で，与觉られたクラ ウンおよび形状をもった入側板が幅広がりがなく，乙 
かも平坦な形状で圧延された場合の出側板厚分布で定 義される（このとき，平均伸びは与学るものとする). また， $E_{p}$ は圧延材の縦剛性係数で，一般に幅方向に 分布をるっていてもよい.

さらに, $w(x)$ は考えているパスの圧延によって生 じる幅方向のひずみであり, 張力分布と次の関係にあ るものと仮定する.

$$
w(x)=A \cdot \gamma \frac{l_{d} h_{m}}{k_{f_{m}}} \frac{\partial^{2} \sigma}{\partial x^{2}}
$$

ここで, $A$ : 幅広がり係数（実験によって決める定 数)

$\gamma:$ 平均圧下率

$l_{d}:$ 接触長さ

$h_{m}:$ 平均板厚

$k_{f m}:$ 平均変形抵抗

また，荷重分布は幅方向の各場所によって 2 次元の 压延荷重式が成立するものとする.

$$
\begin{aligned}
& p(x)=\hat{p}\left(h(x), k_{f}(x), \sigma(x)\right) \\
& \hat{p}: \text { 圧延荷重式 } \\
& k_{f}: \text { 変形抵抗 }
\end{aligned}
$$

方程式(7)（11)式を連立させて解くことによって，板厚 分布 $h(x)$, 張力分布 (形状) $\sigma(x)$, 荷重分布 $p(x)$ などを求めることができる，実際の計算では，積分は マトリックス演算に直して数值解を求めるが，その詳 細は省略する。

\section{3 通常 $4 \mathrm{Hi}$ ミルおよび段付バックアップ}

\section{ロール $4 \mathrm{Hi}$ ミルの板クラウン減少法}

強力に形状，クラウン制御するために，図 5 に示す ようと通常の 4 段ミルのバックアップロール

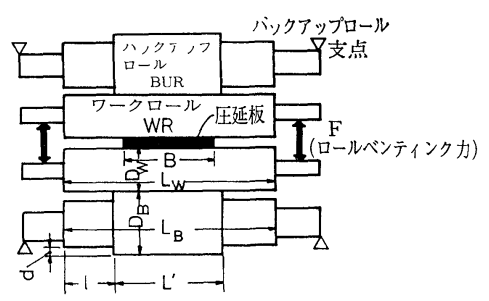

因 5 圧延機各部名称拈よび記号

の胴端部を段削りし、ワークロール (WR) の同端部 の変形を自由にして, WR のたわぬ変形を軽減すると ともに, WR のロールベンディングカ $(F)$ にるWR 軸たわみの 制御範囲を広くした BUR 段付 4 段圧延 機（これ BCM，すなわち Back-up-roll Cutting Mill と呼ぶ）の効果を通常の $4 \mathrm{Hi}$ ミルと比較しな がら理論解析および実機テストによって確認した例に ついて述べる.

\begin{tabular}{|c|c|c|c|}
\hline 項 & 目 -2 & $\begin{array}{l}\text { バックアップ } \\
\text { ロール BUR }\end{array}$ & $\begin{array}{c}\text { ワーク口ール } \\
\text { WR }\end{array}$ \\
\hline & 口 一 径 & $D_{B}=1250 \phi$ & $D_{w}=690 \phi$ \\
\hline & ロール 胴長 & $L_{B}=2000$ & $L_{w}=2000$ \\
\hline & チョック間距離 & 2845 & 2845 \\
\hline & ロールベンダ、 $F$ (ton/chock) & - & $0 \sim 50$ \\
\hline & *有効 BUR 胴長 $\quad L^{\prime}(\mathrm{mm})$ & $750 \sim 2000$ & - \\
\hline & *段 削 り 幅 & $625 \sim 0$ & - \\
\hline & *段 削り 樑さ & 1.5 & - \\
\hline
\end{tabular}

\section{$3 \cdot 1$ 板クラウン制御特性の理論解析}

$80^{\prime \prime}$ ストリップミル（八幡製鉄所 2 熱延工場の仕上
表 I 正延機諸元

* 第 5 スタンドのみ適用

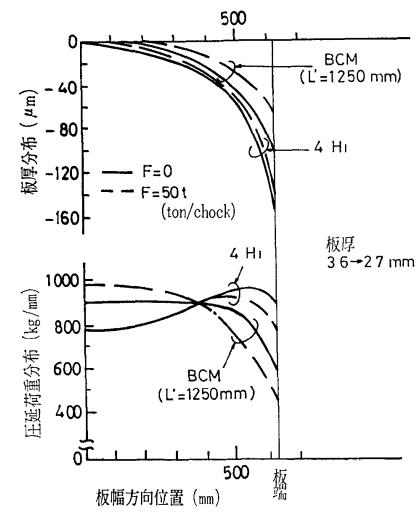

図 6 BCM の板クラウン制御特性

圧延機を参考）を例にとって，表Ｉのような圧延機諸 元を用いて解析した．なお，圧延機の各部の名称およ び記号は図 5 を参照されたい。

図 6 亿板厚抢よび荷重分布の計算結果を示すように， $\mathrm{BCM}$ と $4 \mathrm{Hi}$ ミルによる圧延板の板厚分布を比較す ると， $\mathrm{BCM}$ の方が板クラウンが小さくなり， $4 \mathrm{Hi}$ ミ ルに括ける，ロールベンディングカ $\mathrm{F}=50$ ton/chock よりも BCM による板クラウン減少効果の方が大き いことがわかる。 また， F 自体による板クラウン減

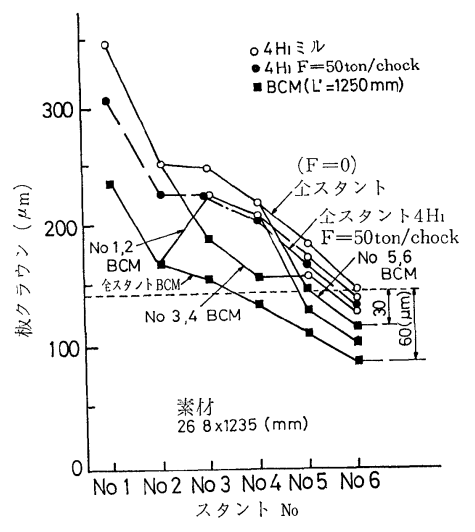

図 7 BCM 配置と板クラウンの推移 (BUR の全胴長 $L_{W}=2000 \mathrm{~mm}$ ) 
表II 各スタンドの BCM 方式の有効ロール胴長と実施期間

(前回の BCM 実験の胴長 $L^{\prime}=1550 \mathrm{~mm}$ )

\begin{tabular}{|c|c|c|c|c|c|c|c|c|c|c|c|}
\hline & \multicolumn{6}{|c|}{ 有効ロール胴長 $L^{\prime}(\mathrm{mm})^{* * *}$} & \multirow{2}{*}{ 実 } & \multirow{2}{*}{ 施 } & \multirow{2}{*}{ 期 } & \multirow{2}{*}{ 間** } & \multirow{2}{*}{$\begin{array}{c}\text { 王 延 䁪 } \\
\text { (ton) }\end{array}$} \\
\hline $\begin{array}{l}\text { 実験 } \\
\text { No. }\end{array}$ & F 1 & F 2 & F 3 & F 4 & F 5 & F 6 & & & & & \\
\hline 第 3 回 & * & * & * & $*$ & 1605 & 1705 & 1976. & 3. & $13 \sim 3$ & 22 & 55696 \\
\hline 4 & $*$ & * & * & 1605 & 1605 & 1705 & 1976. & 4. & $12 \sim 4$. & 21 & 60494 \\
\hline 5 & 1605 & 1605 & 1605 & 1605 & 1605 & 1705 & 1976. & 4. & $30 \sim 5$. & 5 & 65174 \\
\hline
\end{tabular}

注 * 通常 $4 \mathrm{Hi}$ (BUR 胴長 $=1905 \mathrm{~mm}$ )

** 第 3 回直前 1976. 3. 1 3. 10 に全スタンド $4 \mathrm{Hi}$ 条件実施

*** BUR 段削りは上 BUR のみ実施（下 BUR は通常のあのと同じ）

少効果も, $4 \mathrm{Hi}$ ミルの場合より, BCM の方が大きく なっている.

図 7 に通常の $4 \mathrm{Hi}$ スタンドの配置と $\mathrm{BCM}$ スタン ド配置とによる成品クラウンとの関係を示す，同図か ら BCM スタンドは下流側スタンドに配置するのが効 果的であることがわかるが，特に注意を要することは 上流側スタンドのみに配置しても効果が小さいことで ある.下流スタンドで板クラウンを急激に変化させる と, 板形状が悪化するので, 板クラウン変化と形状の 関係をよく把握したらえで，最適配置を考えることが 重要である。

\section{$3 \cdot 2$ 実機による実験結果}

前項で述べた理論解析予測が正しければ，実機によ って検証できることになる. 表IIに示す条件のもとで 80"ストリップミルで実験を行った例について述べる。 通板性に関しては特に異常は認められず，板形状へ の影響は，仕上げミル第 5 スタンド $\left(F_{5}\right)$ のみにBCM を適用した場合には，板幅 900〜1850 mm の範囲で 特に問題点は発生していない. 仕上げミル第 $5 ， 6$ ス タンド $\left(F_{5}, F_{6}\right)$ ともに BCM を適用した場合には, 板幅 $1750 \mathrm{~mm}$ 以上で中伸形状が大きくなり，特にト ップの部がまき取り機に達するまでのフリーテンショ ン部に発生した中伸形状はまき取り後も残存した。

このような形状不良をなくしてさらに大幅に板クラ ウンを減少させるために, BCM 適用スタンド数を増

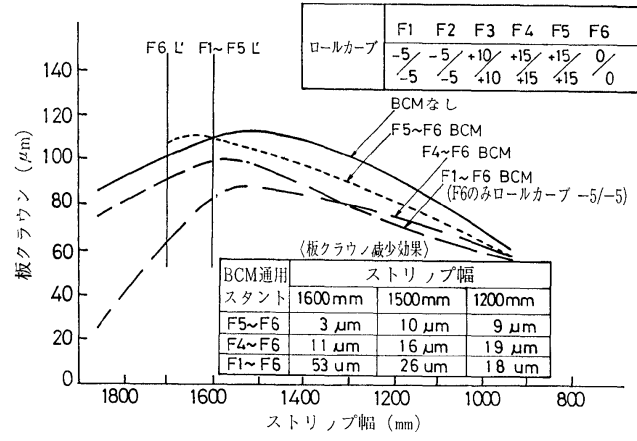

図 $8 \quad \mathrm{BCM}$ スタンド数によるクラウン減少効果の相異
して実験した結果を図 8 に示し，このときの実験条件 を表 II に示した。同表のように有効ロール胴長 $L^{\prime}$ が 長かったため，適用スタンド数の少い場合の効果はは っきりと現れなかったが，適用スタンド数を増したと きの効果の増大は期待されると和りの結果が得られた。 板幅の狭い材料の場合クラウン減少効果の少いのは, 材料幅よりも BUR の段付後の胴長 $L^{\prime}$ が大きいため であり，材料幅に対する適用性が狭いことが欠点とい 党る。

\section{$46 \mathrm{Hi}$ 中間ロールシフトミルの板クラウン減少法}

前節のように，バックアップロールに段をつけ，ワ ークロールを支觉る荷重幅を小さくすることによって， 通常の $4 \mathrm{Hi}$ ミルに比べてストリップ材のクラウンを 小さくできることがわかった．しかしながら，異った 幅の材料を圧延する場合，すべての幅に対して充分な 制御効果を発揮できないといら欠点があるのはやむを 得ない.このような欠点のない圧延機としては図 9 に 示すような, 中間ロール (IMR) を軸方向にシフトし て，ワークロールを支える荷重幅を任意に変えられる ものが，日立製作所によって提案されている.

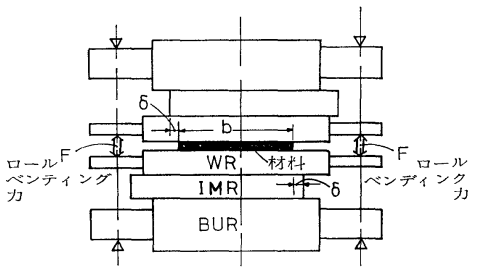

図 $96 \mathrm{Hi}$ ミル概略図

この形式の圧延機は，冷間圧延機としては NH ミ ルといら名称で呼ばれ既に実用に供され, 強力な形状 制御機能を有することが確認されている. クラウン制 御は形状制御とは必ずしも同一の技術ではないが，両 者の間には密接な関係があり，またハードの制御端と しては同一である.

したがって，このミルをホットストリップの圧延に 用いることによって，段付バックアップロールに比べ てはるかに強力なクラウン制御を行らことが可能と推 
定される。

\section{4・1 6 Hi ミルの単スタンド制御機能}

仕上タンデム圧延をシミニレートするため, 試験用 熱間圧延機を用いた実験研究の結果について述べる。

同圧延機の主仕様およびロール寸法を表 III に示す. 材料は軟鋼で粗圧延した 半成品 ( $h=30 \mathrm{~mm}$ 厚)，ま たは仕上げ成品 $(h=15,10 \mathrm{~mm}$ 厚) を幅 $b=400$, $600,800 \mathrm{~mm}$, 長さ $800 \mathrm{~mm}$ に切り出したものを用い た.

図10は板幅 $b=800$, 素材厚 $h=10$ の材料を厚さ $h$ $=3.4$ まで 3 パスで圧延するとき, 最終パスで中間口 ール位置 $\delta$ (中間ロール端の板端に対する相対位置), およびロールベンディングカ $F$ を変えて圧延したとき の板厚分布を示す（压延条件は図中の表に示す）.

表 III 圧延機の主な仕様和よびロール寸法

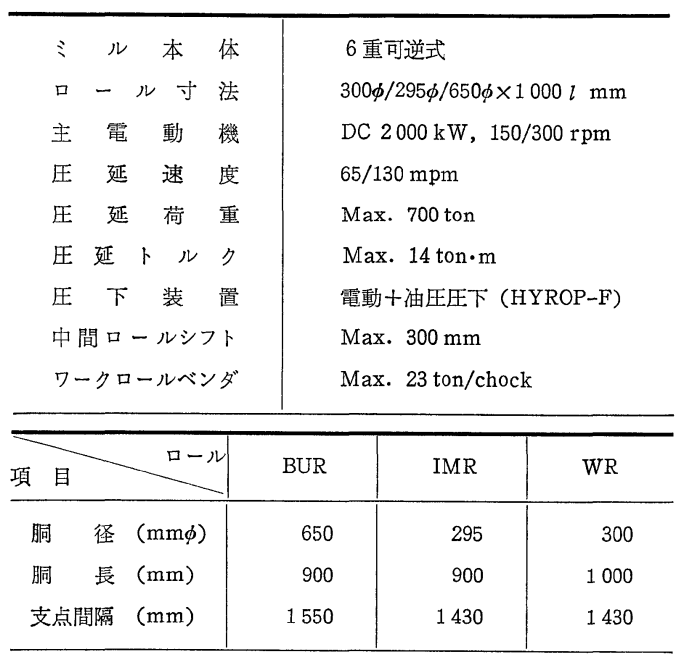
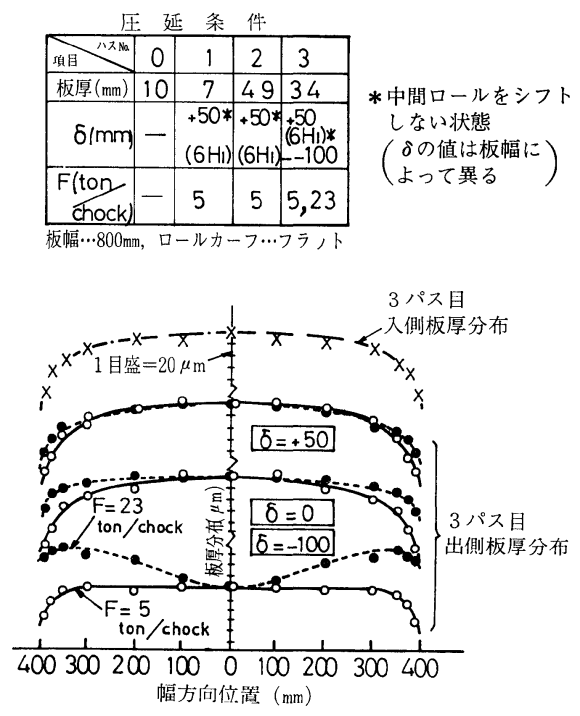

図10 板厚分布之制御条件の関係 $(h=10 \rightarrow 3.4, b=800)$
このよらに $6 \mathrm{Hi}$ ミルでは中間ロールを移動させて， ワークロールを支持する荷重幅を変えることによって， 板厚分布を中凸から中山まで広範囲にクラウンを変え られ，またワークロールベンディングの効果をも大き くできることがわかる。

このようなクラウン制御能力を定量的に表すために， 板端から $25 \mathrm{~mm}$ 点の板厚と, 中央部の板厚との差で 板クラウン $C_{h}$ を定義し(中央が厚い場合を正とする)， 制御条件と板クラウンとの関係を実験によって求め た。

圧延条件は図10中の表に示したものと同じで，3 ㅇ ス目で制御条件 $(\delta, F)$ を種々変えて圧延した。結果 の一例を図 11 に示した. $4 \mathrm{Hi}$ ミルおよび段付バック

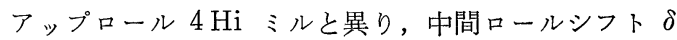
(図 9 にて定義) によって板クラウンを大幅に制御で きることがわかる。

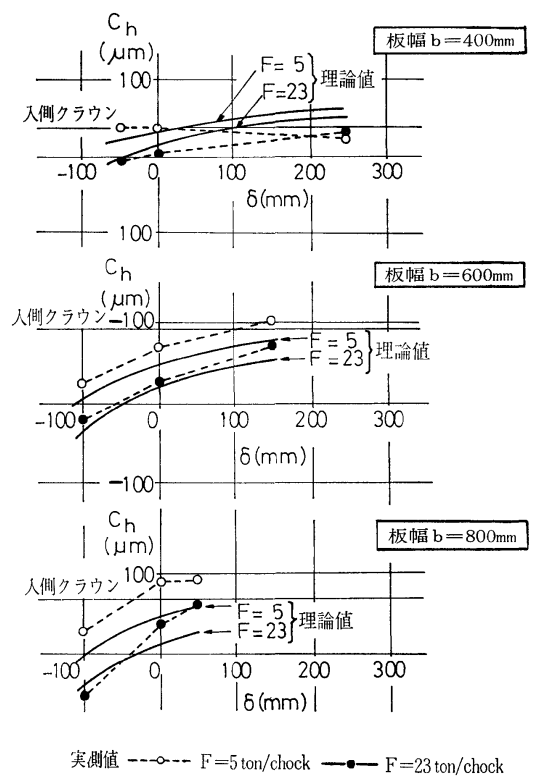

図11 制御条件 $(\delta, F)$ と板クラウンとの関係 (フラットロール, 仕上げ厚 $h=3.4 \mathrm{~mm}$ )

\section{$4 \cdot 2$ 連続圧延における板クラウンの遺伝性}

タンデム圧延に拉けるクラウン制御を考学るらえで， 上流パスで板クラウンを変えた場合，次スタンド以降 の板クラウンにどのような影響を与えるかを知ってお く必要がある。すなわち，入側板厚分布によって出側 板厚分布が変わること，すなわち板クラウンは上流か ら下流に遺伝する。

冷間圧延の場合は板厚分布がほとんど相似に保たれ たまま珐延されるから，板クラウンは汪とんど $100 \%$ 遺伝するわけであり，冷間圧延において板クラウンを 効果的に変えることは困難と思われる．これに対して ホットストリップ圧延の場合は，メタルの板幅方向へ 
の移動がある程度生じ得るから，入側クラウンと出側 クラウンとの対応は一対一ではない.

このような板クラウンの遺伝性を定量的に表すため， 圧延条件を一定にしたときの出側クラウン $C_{h}$ に対す る入側クラウン $C_{H}$ の影響係数 $\eta=\Delta C_{h} / \Delta C_{H}$ (これを 板クラウン遺伝係数と呼ぶことにする）で評価する.

図12にこの遺伝係数を理論特よび実験によって求め た結果を示す. 切板圧延実験では圧延条件を一定に保 つのが難しく相当ばらつきが大きいが，理論計算と比 較してほぼ妥当なクラウン遺伝係数が得られ，板幅が 広く，板厚が薄いほど入側クラウンの影響が大きいと 思われる.ただし，この係数はホットストリップ圧延 では1よりかなり小さく，例党ば上流パスでクラウン を変えても，その影響は各パスごとに指数関数的に減 少するから，クラウン制御は下流パスで行らのが効果・ 的と思われる.
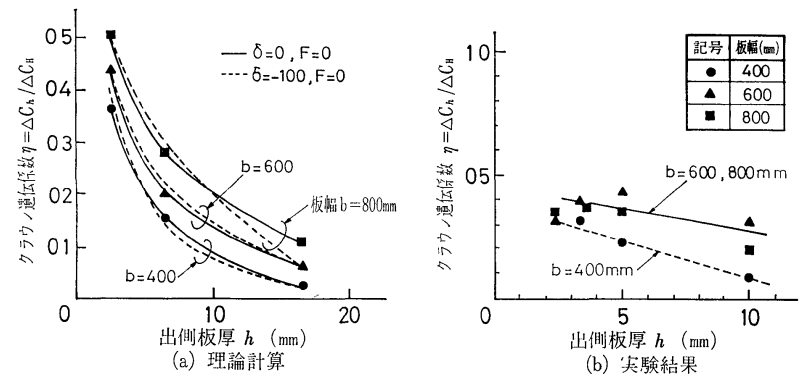

図12 入側クラウンの出側クラウンに及洔す影響

\section{$4 \cdot 3$ 板クラウン変化と形状との関係}

2 節で述べたように板形状と板クラウンとの間には 密接な関係があり，熱間圧延においてはクラウンを所 定の值にすると同時に板形状が良好でなくてはならな w.

図13はクラウン比率の変化量（クラウン比率の出側 と入側の差） $\Delta \varepsilon_{h}$ に対して，伸びひずみ差（波を中央 と板端部の長さの相対差で表したもの） $\Delta \varepsilon_{s}$ をプロッ トした例である，同図は入側クラウン $C_{H}$ の異ったも の（凸和よび凹）をあわせて示したが，压延材の形状 $\Delta \varepsilon_{s}$ は入側クラウンによらず，クラウン比率変化 $\Delta \varepsilon_{h}$ のみで整理できて, 両者はほぼ原点近くを通る直線関 係にあることがわかる．板幅方向の材料の流れがない

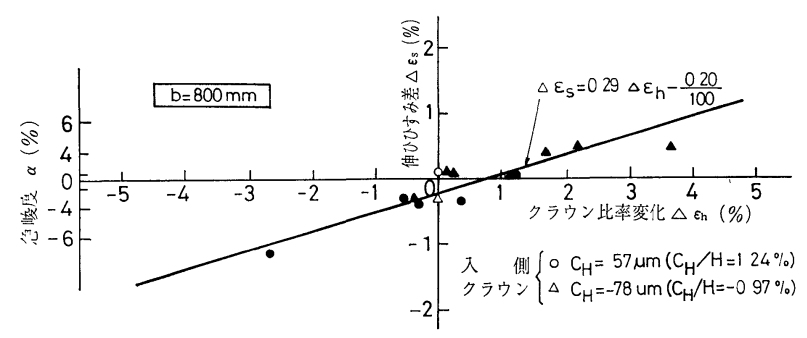

図13 板クラウン変化と形状の関係 $(h=3.4 \mathrm{~mm})$
場合は，この直線のこう配は1になるべきであるが (薄物の冷延の場合に相当する), ホットストリップ圧 延の場合はクラウン比率変化 $\Delta \varepsilon_{h}$ の一部のみが長さ の差 $\Delta \varepsilon_{s}$ に現れることがわかる.

すなわら, 図13の直線のこら配は, クラウン比率変 化（=厚さ方向ひずみ）のどれだけが長さ方向ひずみ 差になるかを示す量であり, 特に形状変化係数と呼ぶ ことにする。

形状変化係数 $\xi$ は圧延材の寸法, ミルディメンジョ ンによって異り，板厚 $h$ の薄いほど，また板幅 $b$ の広 いほど大きい。実機に適用する場合，実機ミルに拈け るほを推定する際の相似則を見つけることが必要であ る. 広範囲の材料寸法および材質（アルミニウム圧延 等）について実験を行った結果，図14に示すように， $\xi$ はほぼ無次元パラメータ $\left(D / D_{0}\right) \times \sqrt{D h} h / b(D$ : ワークロール径) によって整理できる.

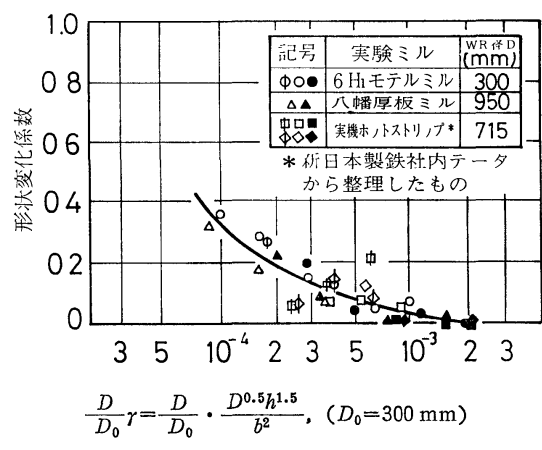

図14 形状变化係数の相似則 $(25 \mathrm{~mm}$ 点クラウン) 実機ホットストリップミルとして，広畑製鉄所で得ら れた実験データを整理したものである．これらのデー タを用いることによって実際のホットストリップミル 圧延のクラウン，形状を求めることができる.

\section{5 各種ミル形式とクラウン制御機能の比較}

ここで，現在板クラウン制御法として有効と考兄ら れる各種のミル形式による板クラウン制御効果の比較 を行う。比較の対象とするミル形式として

(1) 従来の $4 \mathrm{Hi} ミ ル$

(2) $\mathrm{BCM}$ (段付バックアップロール $4 \mathrm{Hi} ミ ル)$

(3) 中間ロールシフト $6 \mathrm{Hi} ミ ル$

（4）異径ロール压延法 (5 Hi 形式)

の 4 形式を用いた.

上記ミルのモデル化和よび諸元について は表 Nに示すと拈りである.

$6 \mathrm{Hi}$ ミルの板クラウン制御法は, BCM 同様，WR とそれを支持するロール胴端を 互いに接触させないようにする方法で, 当 然のことながら BCM と同様の板クラウン 
表 $N \quad$ 各ミル形式のモデル化および諸元

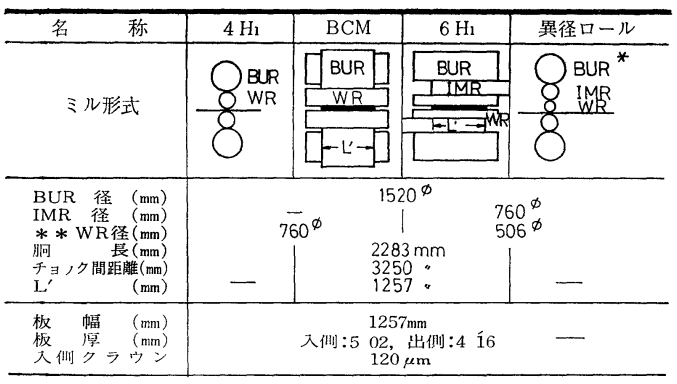

* 界径ロール压延のシュレーションは上側の $6 \mathrm{Hi}$ 圧延と下側の $4 \mathrm{Hi}$ 压延の理諭計算結果を平均した。ただし，压延荷重は 6 Hi 压延に合わせた. (小径ロール)

** WRクラウンなし. (フラット)

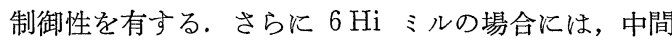
ロールを軸方向にシフトさせて，有効ロール胴長を変 化させることができるので，BCM に比べて，板幅変 化に応じた制御が容易であることはすでに述べたとお りである.ここでは各ミルの効果を単純に比較するた め単一幅に対する比較に止める.

異径ロール圧延法は，上下の WR 径淿なきな差を つけて，大径側の片駆動によって压延する方法である が，上下非対称条件によって圧延荷重が下がるので口 一ルたわみおよび扁平が軽減され, 板クラウンおよび エッジドロップ減少効果が期待される．また，片方の ロールが小径であるので, ロール扁平の軽減およびェ ッジドロップ減少効果が増すと考克られる.

図15は，上記 4 形式のミルによる圧延板のクラウン を棒グラフで表し，比較したものであり，F=0， ton/chock の 3 条件の場合を示す.

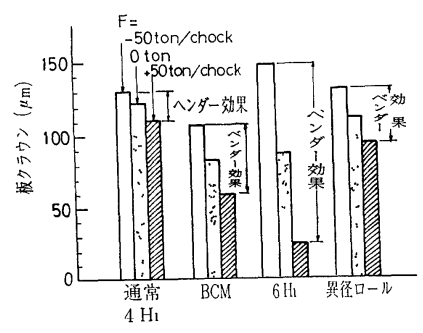

図15 各ミル形式の板クラウンの比較

$\mathrm{F}=0$ で，各ミルの板クラウンを比較すると， $\mathrm{BCM}$, $6 \mathrm{Hi}$ ミルはともに，4 Hi ミルに比べて約 $35 \mu \mathrm{m} の$ 板クラウン減少効果があるのに対し, 異径ロール圧延 法では約 $10 \mu \mathrm{m}$ の減少効果に止まる.

$\mathrm{F}$ を -50 ton/chock〜+50 ton/chock の範囲で変 動させると, $4 \mathrm{Hi}$ ミルでは約 $20 \mu \mathrm{m}$ の板クラウン制 御範囲であるのに対して，BCM では約 $50 \mu \mathrm{m}, 6 \mathrm{Hi}$
ミルでは $130 \mu \mathrm{m}$ と大きな制御範囲が岗るが，異径口 一ル压延では約 $35 \mu \mathrm{m}$ であり， $4 \mathrm{Hi}$ ミルに比べて若 亩制御範囲が広くなっている。

また著者らは $6 \mathrm{Hi}$ 中間ロールシフトミルと同等の 効果をもったミルとして, バックアップロールのスリ ーブシフト方式の $4 \mathrm{Hi}$ ミルの研究を行って, BCM の欠点をなくすことができた。

最近，板形状制御ミルとして，4 Hi のバックアップ ロールのスリーブを油圧で膨張させてクラウンを付け る VCロール (Variable Crown) が開発されて, 冷 間圧延の形状制御に効果があることが報告されている。

\section{6 結言}

ホットストリップ仕上げミルに护ける板クラウン特 よび板形状の造形性について, 通常の $4 \mathrm{Hi} ミ ル と$ 比

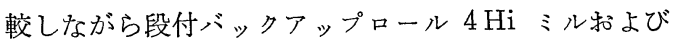
中間ロールシフト $6 \mathrm{Hi}$ ミルを例に上げて述べた。

これらの圧延機は, 従来の $4 \mathrm{Hi}$ ミルに比べて格段 飞優れたクラウン，形状制御機能を有しており，これ らの圧延機を仕上ミルに適用することによって強力な クラウン制御を行うことが可能である．また，通板形 状拉よび成品の平坦度を確保するために, これらのク ラウン制御ミルを後段に連続して配置し, 複数のスタ ンドで操作することによってクラウン制御を行うこと が重要である.

\section{参 考 文 献}

1) 徐田征雄他, 塑性加工春季講演会前刷, 41 (1978).

2）土屋健治，若子敦弘，福田武幸，猪井善生，鉄と鋼，61, 202 (1975).

3）高島義昭，木崎睆司他，石川島播磨技報， 19， 133 (1979).

4）例光ば，中島浩衛，菊間敏夫，大上哲郎，塑性加工春季 講演会前刷， 25 (1978).

5）児子 茂, 古谷 尚他, 塑性加工連合講演会前刷, 11, 53 (1975).

6）中島浩衛, 菊間敏夫他, 塑性加工連合講演会前刷, $\mathbf{1 1}$, 9 (1979).

7) 中島浩衛, 菊間敏夫他, 日立評論, 61 (1979).

8) Nakajima, K., etc., International Conference on Steel Rolling, Japan, 1, 544 (1980).

9）中島浩衛他，製鉄研究，299，92 (1979).

10）中島浩衛他, 塑性加工春季講演会前刷, 37 (1977).

11）加古幸博, 阿高松男他, 塑性加工春季講演会前刷, 453 (1979).

12) Metals and Materials, May (1980).

13）向井哲也，小野博幸他，塑性加工春季講演会前刷， 73 (1980). 